\title{
PENGARUH MODAL INTELEKTUAL, ORIENTASI ETIKA, DAN GENDER TERHADAP SENSITIVITAS ETIS MAHASISWA
}

\author{
Zulhawati (Zulhawati.uty@gmail.com) \\ UTY Yogyakarta
}

\begin{abstract}
Abstrak
Penelitian ini menguji pengaruh modal intelektual, orientasi etika dan gender terhadap sensitivitas etis pada proses pengambilan keputusan etis oleh mahasiswa. Pengukuran sensitivitas etis oleh mahasiswa menggunakan nilai etis organisasi dengan kuesioner yang dikembangkan dari kode etik mahasiswa, modal intelektual menggunakan tingkat kesadaran moral dan orientasi etika digunakan Ethical Position Questionnaire berdasarkan pada dua dimensi etis (idealisme dan relativisme). Rancangan penelitian ini menggunakan crosssectional dengan responden mahasiswa S1. Hasil penelitian reliabilitas menunjukkan cronbach's alpha lebih besar dari 0,6 dan pengujian validitas konstruk menunjukkan bahwa variabel mempunyai validitas konstruk lebih besar dari rule of tumb 0,5 .
\end{abstract}

Hasil penelitian menunjukkan bahwa modal intelektual dan orientasi etika idelisme berpengaruh terhadap sensitivitas etis mahasiswa. Sedangkan untuk orientasi relativisme dan gender tidak berpengaruh terhadap sensitivitas etis mahasiswa. Hal ini menunjukkan bahwa pendidikan memiliki peran penting dan harus mampu menciptakan calon pebisnis yang kualified dan etis, memiliki kecerdasan intelektual setara dengan kepekaan nurani, sehingga mampu menciptakan sebuah investasi dan esensi yang sesungguhnya dari konsep human capital.

Keywords; modal intelektual, orientasi etika, gender, sensitivitas etis,

\section{PENDAHULUAN}

Kasus Sunbean, Enron, WorldCom, Tyco, Health South di Amerika, Parmalat di Italia, HIH Insurance di Australia, Bank Global, Bank Lippo, Century, Telkom dan Hambalang merupakan contoh terjadinya pelanggaran etika yang dilakukan oleh para pelaku bisnis di Indonesia. Kasus-kasus kecil berkaitan dengan makanan ringan, misalnya mi bekas yang sudah membusuk disulap jadi makanan ringan kemasan, pembuatan makanan dengan pewarna tekstil dan lain-lain kasus pelanggaran etika hanya demi meningkatkan laba, atau mungkin hanya sekedar untuk meningkatkan penghasilan. Wajar bila ada kesimpulan, dalam bisnis, satu-satunya etika yang diperlukan hanya sikap baik dan sopan kepada pemilik. Harus diakui, kepentingan utama bisnis adalah menghasilkan keuntungan maksimal bagi pemilik. Fokus itu membuat perusahaan yang berpikir pendek dengan segala cara berupaya melakukan hal-hal yang dapat meningkatkan keuntungan. Kompetisi semakin ketat dan konsumen lebih mementingkan sesuatu yang praktis dan instan sering menjadi faktor pemicu perusahaan mengabaikan etika dalam berbisnis.

Berdasarkan kasus-kasus tersebut, sebagian besar merupakan perilaku berkaitan dengan etika yang dihadapi para pelaku bisnis, faktor penting dalam perilaku pengambilan keputusan etis adalah faktor-faktor yang secara unik berhubungan dengan individu pembuat keputusan dan variabel-variabel yang merupakan hasil dari proses sosialisasi dan pengembangan masingmasing individu seperti ciri pembawaan sejak lahir (gender, umur, kebangsaan) dan faktor 
organisasi, lingkungan kerja dan profesi (Paolillo dan Vitell 2002). Berkaitan dengan etika tersebut, pendidikan diharapkan tetap memainkan peran utama dalam pengembangan professional entry level employee. (Russell dan Smith 2003) menyoroti bahwa kegagalan bisnis yang melibatkan salah satu kantor akuntan publik global, tidak terlepas dari desain kurikulum pendidikan tinggi yang dirasa belum mampu menyediakan materi yang cukup untuk mempersiapkan mahasiswa sebagai calon-calon pebisnis. (Clark 2003) menyatakan bahwa masyarakat dan pandangannya mempunyai pengaruh secara langsung terhadap perilaku etis, sedangkan para pendidik dan praktisi belum mampu mengembangkan konsepkonsep etika yang sesuai dengan keadaan dunia bisnis yang sedang berlangsung.

Namun, belakangan beberapa akademisi dan parktisi bisnis melihat adanya hubungan sinergis antara etika dan laba. Menurut mereka, justru di era kompetisi yang ketat ini, reputasi baik merupakan sebuah competitive advantage yang sulit ditiru. Salah satu kasus yang dijadikan acuan adalah Johnson \& Johnson (J\&J) menangani kasus keracunan Tylenol tahun 1982. Pada kasus itu tujuh orang dinyatakan mati secara misterius setelah mengkonsumsi Tylenol di Chicago, tapi setelah itu J\&J segera menarik produknya dan bekerjasama dengan polisi, FBI, dan FDA (BPOM-nya Amerika Serikat) menyelidiki, hasilnya membuktikan, keracunan itu disebabkan oleh pihak lain yang memasukkan sianida ke botol-botol Tylenol. Biaya yang dikeluarkan dalam kasus ini lebih dari 100 juta dollar AS. Namun, hasil kesigapan dan tanggung jawab yang mereka tunjukkan, perusahaan itu berhasil membangun reputasi bagus yang masih dipercaya hingga kini. Begitu kasus diselesaikan, Tylenol dilempar kepasaran dengan penutup lebih aman dan produk ini segera kembali memimpin pasar (market leader) di AS.

Berdasar latar belakang tersebut, penelitian ini menguji apakah modal intelektual, orientasi etis yaitu orientasi idealisme dan relativisme, serta gender mempengaruhi pengembilan keputusan etis oleh mahasiswa. Responden dalam penelitian ini dipilih mahasiswa salah satu Perguruan Tinggi Swasta di Jogjakarta karena mereka akan menjadi calon pebisnis yang secara intelektual di didik dan dipersiapkan untuk menjadi pebisnis yang etis. Manfaat yang diharapkan dari penelitian ini adalah: (1) membantu mahasiswa dalam memahami etika bisnis dan membantu dalam memecahkan permasalahan saat menghadapi dilemma etis, (2) bagi pendidik dapat menjadi masukan untuk mengembangkan konsep pendidikan etika dengan lebih memperhatikan perkembangan moral dan pertimbangan etis mahasiswa agar dapat membentuk perilaku etis mahasiswa sebagai calon pebisnis.

\section{LANDASAN TEORI DAN PENGEMBANGAN HIPOTESIS}

\section{Teori Disonansi Kognitif dan Teori Perilaku Berencana}

Menurut teori disonansi kognitif, pada dasarnya manusia bersifat konsisten dan akan cenderung mengambil sikap-sikap yang tidak bertentangan satu sama lain, serta menghindari melakukan tindakan yang tidak sesuai dengan sikapnya. Namun demikian, dalam kenyataannya manusia seringkali terpaksa harus melakukan perilaku yang tidak sesuai dengan sikapnya (Severin 2005). Arti disonansi adalah adanya suatu inkonsistensi dan perasaan tidak suka yang mendorong orang untuk melakukan suatu tindakan untuk keluar dari ketidaknyamanan tersebut dengan dampak-dampak yang tidak dapat diukur.

Disonansi terjadi apabila terdapat hubungan yang bertolak belakang akibat penyangkalan dari satu elemen kognitif terhadap elemen lain, antara elemen-elemen kognitif dalam diri 
inidividu. Disonansi kognitif mengacu ada inkonsistensi dari dua atau lebih sikap-sikap individu, atau inkonsistensi antara perilaku dan sikap. Dalam teori ini, unsur kognitif adalah setiap pengetahuan, opini, atau apa saja yang dipercayai orang mengenai lingkungan, diri sendiri atau perilakunya. Menurut (Severin 2005) teori ini mampu membantu untuk meprediksi kecenderungan individu dalam mengubah sikap dan perilaku dalam rangka untuk mengurangi disonansi yang terjadi.

Menurut (Ajzen 1991) dalam Theory Planned of Behavior didasarkan pada asumsi bahwa manusia biasanya akan berperilaku pantas (behave in a sensible manner). Tujuan dan manfaat dari teori ini adalah untuk meramalkan dan memahami pengaruh-pengaruh motivasi perilaku, baik kemauan individu itu sendiri maupun bukan kemauan dari inidividu tersebut. Pada dasarnya teori ini merupakan fungsi dari tiga dasar determinan. Pertama, terkait dengan sikap dasar seseorang (person in nature) disebut dengan attitude toward the behavior (sikap seorang terhadap perilaku). Fungsi dasar determinan yang kedua menggambarkan pengaruh sosial (sosial influence) yang disebut norma subjektif (subjective norm). Persepsi seseorang terhadap perilaku yang bersifat normatif (sesuai dengan norma yang dapat diterima orang lain) akan membentuk suatu norma subyektif dalam diri seseorang. Ketiga yang berkaitan dengan isu kontrol (issues of control) yang disebut dengan perceived behavioral control (persepsi mengenai control perilaku). Faktor ini berkaitan dengan pengalaman masa lalu dan persepsi seseorang mengenai seberapa sulit untuk melakukan suatu perilaku tertentu.

\section{Etika}

Menurut (Cytron 2005) ada beberapa definisi etika tergantung pada kontek yang dibicarakan. Etika berarti watak kesusilaan atau adat kebiasan. Etika biasanya berkaitan erat dengan perkataan moral yang berarti juga adat kebiasaan atau cara hidup seseorang dengan melakukan perbuatan yang baik (kesusilaan), yang menghindari hal-hal yang buruk. Dalam beberapa konteks, etika sinonim dengan filosofi moral, yang mencoba menjawab pertanyaan teoritis mengenai sifat dan rasionalitas moral. Menurut Teori etika Michael Davis seperti yang telah dikutip oleh (Ashgate 2002 dalam Cytron 2005), etika didefinisikan sebagai berikut: standar untuk setiap orang (yang secara rasional terbaik bagi mereka) sehingga orang lain ingin mengikutinya, bahkan jika mungkin mereka harus mengikutinya. Sedangkan dalam kasus lain, etika berarti kode etik khusus yang diterapkan bagi para anggota profesi tertentu. Salah satu pengertian etika menurut (Mappes 1998 dalam Huss dan Denis 1993) adalah Etika dapat didefinisikan sebagai falsafah ilmu moral, dan karena itu, moralitas adalah jelas sebagai karakteristik subjek soal etika. Dari definisi-definisi tersebut, ide utama tentang etika merupakan suatu "aturan main" tertentu yang mengatur perilaku dan seharusnya dipatuhi oleh para anggotanya.

\section{Modal Intelektual}

Menurut Human Capital Theory, modal intelektual memiliki peran yang sangat penting dan strategis di perusahaan. Intelektual kapital ini dapat didorong melalui pendidikan, pelatihan dan pengalaman (Becker 1964). Menurut (Nahapiet dan Ghoshal 1998), intelektual kapital merupakan pengetahuan dan kemampuan yang dimiliki oleh suatu kolektivitas sosial, seperti sebuah organisasi, komunitas intelektual, atau praktek professional. Intellectual kapital mewakili sumber daya yang bernilai dan kemampuan untuk bertindak yang didasarkan pada pengetahuan. 
Modal manusia seperti dideskripsikan oleh (Nahapiet dan Ghoshal 1998) adalah atributatribut kualitas populasi (manusia) yang diperoleh (acquired vs innate human abilities) yang diwariskan secara genetik, yang bernilai dan dapat ditingkatkan melalui investasi yang tepat. Modal manusia terdiri atas, 1) ciri-ciri pribadi yang dibawa ke dalam pekerjaan (seperti kecerdasan, energi, sikap positif, dapat dipercaya, berkomitmen), 2) kemampuan untuk belajar (ketrampilan, imajinasi, kreativitas, kelincahan berpikir dan bekerja, kapabilitas mengeksekusi), 3) motivasi untuk berbagi informasi dan pengetahuan tersebut, knowledge dan knowing capability. Namun, dalam penjelasannya, dibedakan dua jenis pengetahuan, yakni pengetahuan individual, baik yang eksplisit maupun yang tacit (automatic knowledge), serta pengetahuan sosial yang juga terdiri atas yang eksplisit (objectified knowledge) dan yang tacit (collective knowledge).

Menurut (Bontis 2005), modal intelektual pada level bangsa dipahami sebagai nilai-nilai tersembunyi (hidden values) dari individu-individu, perusahan-perusahaan, institusi-institusi, dan masyarakat serta wilayah yang merupakan sumber nyata maupun potensial bagi penciptaan nilai/kesejahteraan. Lebih jauh, dengan mengadopsi model (Edvinsson dan Malone 1997) dalam (Bontis 2005) merumuskan komponen modal intelektual bagi konteks bangsa atau masyarakat. Menurutnya dalam konteks ini, modal intelektual terdiri atas human capital, organizational capital (dipilah menjadi renewal capital dan process capital), serta market capital. Keseluruhan hal itulah yang membentuk kesatuan entitas modal intelektual.

Pendidikan, pelatihan dan pengalaman akan mengubah kemampuan emosional dan kognitif seseorang seiring berjalannya usia dan kemampuan mereka untuk menghadapi isu moral yang berkembang. Pada usia anak-anak secara jujur mampu mengatakan apa yang benar dan apa yang salah, setelah dewasa untuk memutuskan sesuatu memulai mengevaluasi secara kritis standar moral yang ada dan konsekuensinya, dan mengevaluasi ketika tidak konsisten atau tidak masuk akal (Paolillo dan Vitell 2002)

\section{Orientasi etika}

Orientasi etika (ethical orientation atau ethical ideology) berarti mengenai konsep diri dan perilaku pribadi yang berhubungan dengan individu dalam diri seseorang. (Cohen dkk. 1996) menyatakan bahwa setiap orientasi etika individu, pertama-tama ditentukan oleh kebutuhannya. Kebutuhan tersebut berinteraksi dengan pengalaman pribadi dan sistem nilai individu yang akan menentukan harapan atau tujuan dalam setiap perilakunya sehingga pada akhirnya individu tersebut menentukan tindakan apa yang akan diambilnya. Orientasi Etika menurut (Forsyth 1992 dalam Barnett dkk. 1994) dioperasionalisasikan sebagai kemampuan individu untuk mengevaluasi dan mempertimbangkan nilai etika dalam suatu kejadian. Orientasi etika menunjukkan pandangan yang diadopsi oleh masing-masing individu ketika menghadapi situasi masalah yang membutuhkan pemecahan dan penyelesaian etika atau dilema etika.

Kategori orientasi etika yang dibangun oleh (Forsyth 1992 dalam Barnett dkk. 1994) menyatakan bahwa manusia terdiri dari dua konsep yaitu idealisme versus pragmatisme, dan relativisme versus nonrelativisme yang ortogonal dan bersama-sama menjadi sebuah ukuran dari orientasi etika individu. Idealisme menunjukkan keyakinan bahwa konsekuensi sebuah keputusan yang diinginkan dapat diperoleh tanpa melanggar nilai-nilai luhur moralitas. Dimensi ini dideskripsikan sebagai sikap individu terhadap suatu tindakan dan bagaimana tindakan itu berakibat kepada orang lain. Individu dengan idealisme yang tinggi percaya bahwa tindakan yang etis seharusnya mempunyai konsekuensi yang positif dan 
selalu tidak akan berdampak atau berakibat merugikan kepada orang lain sekecil apapun (Barnett dkk. 1994). Di lain pihak, pragmatisme mengakui hasil keputusan adalah yang utama dan jika perlu mengabaikan nilai-nilai moralitas untuk mendapatkan keuntungan yang lebih besar.

Konsep relativisme menunjukkan perilaku penolakan terhadap kemutlakan aturan-aturan moral yang mengatur perilaku individu yang ada. Orientasi etika ini mengkritik penerapan prinsip-prinsip aturan moral yang universal. Relativisme menyatakan bahwa tidak ada sudut pandang suatu etika yang dapat diidentifikasi secara jelas merupakan 'yang terbaik', karena setiap individu mempunyai sudut pandang tentang etika dengan sangat beragam dan luas. Kebalikannya, orientasi etika non-relativisme (atau absolutisme) menunjukkan pengakuan adanya prinsip-prinsip moral dengan kewajiban-kewajiban yang mutlak.

Orientasi Etika idealisme merupakan sikap yang menganggap bahwa tindakan yang tepat atau benar akan menimbulkan konsekuensi hasil yang diinginkan. Idealisme mengacu pada luasnya seseorang individu percaya bahwa keinginan dari konsekuensi dapat dihasilkan tanpa melanggar petunjuk moral. Seorang individu yang idealis mempunyai prinsip bahwa mereka tidak akan melakukan tindakan yang berkonsekuensi negatif. Seorang yang idealis akan menghindari tindakan yang dapat merugikan orang lain. Idealisme mengacu pada suatu hal yang dipercaya oleh individu dengan konsekuensi yang dimiliki dan diinginkannya tidak melanggar nilai-nilai moral.

Seorang yang idealis akan memegang teguh perilaku etis, sehingga individu yang tingkat idealismenya tinggi cenderung menjadi whistle blower dalam menghadapi situasi yang di dalamnya terdapat perilaku tidak etis. Seorang yang idealis juga akan mengambil pilihan yang paling sedikit mengakibatkan kerugian pada individu lain. Sebaliknya individu dengan idealisme yang lebih rendah, mereka menolak prinsip moral universal, mereka berpendapat bahwa terkadang perlu melakukan tindakan negatif untuk mencapai tujuan yang diinginkan.

Orientasi Etika relativisme merupakan teori yang mengatakan bahwa tindakan dapat dikatakan etis atau tidak, benar atau salah, tergantung kepada masyarkat itu. Teori ini menganut aturan etika yang sifatnya tidak universal karena etika dilatar belakangi oleh budaya masing-masing dengan aturan yang berbeda-beda. Individu yang memiliki tingkat relativisme yang tinggi menganggap bahwa tindakan moral tergantung pada situasi dan sifat individu yang terlibat. Dengan kata lain, relativisme etis maupun relativisme moral adalah pandangan bahwa tidak ada standar etis yang secara absolute benar. Dalam penalaran moral seorang individu, ia harus selalu mengikuti standar moral yang berlalu dalam masyarakat dimanapun berada.

\section{Sensitivitas etis}

Sensitivitas etis merupakan kemampuan untuk menyadari nilai-nilai etika atau moral dalam suatu keputusan. Keputusan etis (ethical decision) per definisi adalah sebuah keputusan yang baik secara legal maupun moral dapat diterima oleh masyarakat luas (Trevino 1986; Jones 1991). Beberapa review tentang penelitian etika (Louwers dkk. 1997; Loe dkk. 2000; Paolillo dan Vitell 2002) mengungkapkan beberapa penelitian empirik tentang pengambilan keputusan etis. Mereka menyatakan bahwa salah satu determinan penting perilaku pengambilan keputusan etis adalah faktor-faktor yang secara unik berhubungan dengan individu pembuat keputusan dan variabel-variabel yang merupakan hasil dari proses sosialisasi dan pengembangan masing-masing individu. Faktor-faktor individual tersebut 
meliputi variabel-variabel yang merupakan ciri pembawaan sejak lahir (gender, umur, kebangsaan dan sebagainya). Sedangkan faktor-faktor lainnya adalah faktor organisasi, lingkungan kerja, profesi dan sebagainya.

Zeigenfuss dan Martison (2002) menyatakan bahwa model pengambilan keputusan etis terdiri dari 4 (empat tahapan), yaitu pertama pemahaman tentang adanya isu moral dalam sebuah dilema etika (recognizing that moral issue exists). Dalam tahapan ini menggambarkan bagaimana tanggapan seseorang terhadap isu moral dalam sebuah dilema etika. Kedua adalah pengambilan keputusan etis (make a moral judgment), yaitu bagaimana seseorang membuat keputusan etis. Ketiga adalah moral intention yaitu bagaimana seseorang bertujuan atau bermaksud untuk berkelakuan etis atau tidak etis. Sedangkan keempat adalah moral behavior, yaitu bagaimana seseorang bertindak atau berperilaku etis atau tidak etis.

Jones (1991) menyatakan ada 3 unsur utama dalam pengambilan keputusan etis, yaitu pertama, moral issue, menyatakan seberapa jauh ketika seseorang melakukan tindakan, jika dia secara bebas melakukan tindakan itu, maka akan mengakibatkan kerugian (harm) atau keuntungan (benefit) bagi orang lain. Dalam bahasa yang lain adalah bahwa suatu tindakan atau keputusan yang diambil akan mempunyai konsekuensi kepada orang lain. Kedua adalah moral agent, yaitu seseorang yang membuat keputusan moral (moral decision). Ketiga adalah keputusan etis (ethical decision) itu sendiri, yaitu sebuah keputusan yang secara legal dan moral dapat diterima oleh masyarakat luas.

Perkembangan penalaran moral (cognitive moral development), sering disebut juga kesadaran moral (moral reasoning, moral judgment, moral thinking), merupakan faktor penentu yang melahirkan perilaku moral dalam pengambilan keputusan etis, sehingga untuk menemukan perilaku moral yang sebenarnya hanya dapat ditelusuri melalui penalarannya. Artinya, pengukuran moral yang benar tidak sekedar mengamati perilaku moral yang tampak, tetapi harus melihat pada kesadaran moral yang mendasari keputusan perilaku moral tersebut. Dengan mengukur tingkat kesadaran moral akan dapat mengetahui tinggi rendahnya moral tersebut (Jones 1991).

\section{Gender}

Secara kodrati karakter yang dimiliki antara pria dan wanita memang berbeda. Pengaruh dari perbedaan gender terhadap penilain etis sangat komplek dan tidak pasti. Hasil penelitian (Sankaran dan Bui 2003) menunjukkan bahwa seorang perempuan akan lebih peduli terhadap perilaku etis dibanding laki-laki. Pendapat lain mengenai perbedaan yang berdasarkan jenis kelamin dalam pemikiran moral, berdasarkan fakta bahwa struktur penghargaan dan pendorong suatu profesi yang diberikan memaksa semuanya untuk mengembangkan kepercayaan-kepercayaan moral dan nilai-nilai moral yang serupa. Karenanya, laki-laki dan perempuan pada profesi yang sama akan menunjukkan perilaku moral serupa.

\section{Modal Intelektual dan Sensitivitas Etis}

Theory Planned of Behavior mengasumsikan bahwa manusia biasanya akan berperilaku pantas dengan dasar tiga fungsi dasar determinan, yaitu : (1) attitude toward the behavior, (2) subjective norm, (3) perceived behavior control. Fungsi dasar determinan attitude toward behavior dan subjective norm mampu menjelaskan sikap dari diri sesorang, sesuai dengan lingkungan dan norma-norma yang diyakini orang-orang di sekitarnya. Orang lain akan menilai seseorang yang berkeahlian tinggi pasti akan berperilaku baik, oleh karena itu setiap 
individu dengan keahlian tertentu biasanya akan bersikap sesuai dengan bagaimana persepsi orang lain terhadap dirinya.

Mendasari teori ini, maka modal intelektual didudukkan di tempat strategis dalam konteks kinerja atau kemajuan suatu organisasi atau masyarakat, fenomena ini merujuk berdasar pergeseran tipe masyarakat dari masyarakat industrialis dan jasa ke masyarakat pengetahuan. (Drucker 1997, 2001) misalnya meramalkan datangnya dan sekaligus mendeskripsikan pergeseran ke arah era masyarakat pengetahuan (knowledge society). Dalam masyarakat tipe ini, pengetahuan, juga kapabilitas untuk belajar (learning capability), dan tindakan berinvestasi untuk maksud membangun basis-basis intelektual merupakan penggerak perubahan yang cepat dalam masyarakat dan karenanya manusia sebagai pekerja pengetahuan (knowledge worker) menjadi aktor utamanya. Intellectual capital adalah materi intelektual (pengetahuan, informasi, property intelektual, pengalaman) yang dapat digunakan untuk menciptakan kekayaan. Ini adalah suatu kekuatan akal kolektif atau seperangkat pengetahuan yang berdaya guna (Stewart, 1997). Berdasarkan uraian tersebut, diatas maka hipotesis kedua dari penelitian ini adalah:

$\mathrm{H}_{1}$ : Terdapat pengaruh positif antara modal intelektual dengan sensitivitas etis mahasiswa

\section{Orientasi Etika dan Sensitivitas Etis}

Faktor yang penting dalam penilaian dan perilaku etis adalah kesadaran para individu bahwa mereka adalah agen moral. Kemampuan untuk menyadari adanya nilai-nilai etik atau moral dalam suatu keputusan inilah yang disebut sensitivitas etis. Keputusan atau tindakan yang berkaitan dengan masalah moral harus mempunyai konsekuensi buat yang lain dan harus melibatkan pilihan atau kerelaan memilih dari sang pembuat keputusan. Definisi ini jadi memiliki pengertian yang luas, karena keputusan seringkali memiliki konsekuensi bagi pihak lain dan kerelaan untuk memilih hampir selalu merupakan pemberian, walaupun pilihanpilihan itu seringkali memiliki risiko yang berat. Dalam beberapa hal, banyak keputusan dinilai sebagai keputusan moral hanya karena memiliki kandungan moral, padahal tidak demikian. Seperti yang dikatakan oleh (Jones 1991), bahwa suatu keputusan dapat dinilai dari segi moral jika pada saat keputusan itu dibuat dengan memperhitungkan atau memasukkan nilai-nilai moral.

Ratdke (2000) mengemukakan bahwa sensitivitas etis mahasiswa merupakan gambaran atau proksi dari tindakan etis mahasiswa setelah lulus. Sensitivitas merupakan ciri-ciri tindakan yang mendeteksi kemungkinan lulusan dalam berperilaku etis. Apabila sebagai calon pebisnis, mahasiswa telah berperilaku tidak etis maka kemungkinan setelah lulus akan berperilaku tidak etis. Hal ini perlu dideteksi sejak awal sebagai awal untuk mencegah perilaku tidak etis melalui cakupan atau muatan kurikulum etika, sehingga sebagai calon pebisnis mampu bersaing dan bertindak secara profesional. Keputusan etika menjadi rumit untuk dinilai terutama karena peraturan-peraturan yang ada tidak secara sempurna dapat menjadi sarana terwujudnya keputusan yang etis. Seringkali terjadi bahwa keputusan yang legal tidak selalu etis. Keadaan yang bias ini seringkali menjadi pemicu adanya masalahmasalah etika.

Model yang diajukan Trevino (1986) dapat jelaskan yaitu ketika seseorang dihadapkan pada sebuah dilema etika maka individu tersebut akan mempertimbangkannya secara kognitif dalam benaknya. Hal ini searah dengan pernyataan Jones (1991) tentang moral issue yang ada dalam dilema etika tersebut bahwa kesadaran kognitif moral seseorang tergantung kepada 
level perkembangan moral. Pembentukan pemahaman tentang moral issue tersebut akan tergantung kepada faktor individual (pengalaman, orientasi etika dan komitmen kepada profesi) dan faktor situasional (nilai etika organisasi). Mahasiswa yang memiliki idealisme tinggi akan memberikan persepsi yang positif terhadap perilaku etis, sedangkan orientasi relativisme tidak ada standar etis yang secara absolute benar. Individu yang tergolong idealisme lebih sensitif terhadap situasi yang melanggar norma atau aturan, sedangkan individu yang tergolong relativisme justru tidak mengindahkan prinsip-prinsip yang ada dan lebih melihat pada keadaan sekitar sebelum akhirnya bertindak merespon suatu kejadian yang melanggar etika. Individu relativis cenderung mengabaikan prinsip dan kurang bertanggung jawab. Berdasarkan penjelasan tersebut maka dalam penelitian ini dihipotesiskan:

$\mathrm{H} 2$ : Orientasi etika idealisme mahasiswa mempunyai pengaruh positif terhadap sensitivitas etis mahasiswa

H3: Orientasi etika relativisme mahasiswa mempunyai pengaruh terhadap sensitivitas etis mahasiswa

\section{Gender dan Sensitivitas Etis}

Teori disonansi kognitif membantu menjelaskan pengaruh gender terhadap sensitivitas etis. Sifat psikologis manusia yang pada dasarnya mencari kenyamanan dalam segala situasi membuat teori ini menjadi dasar mengapa wanita dan pria berbeda cara berpikir dan berperilaku serta pengolahan informasi. Setiap individu dituntut memiliki kemampuan dalam memproses informasi (secara kognitif). Hasil penelitian (Chung dan Monroe 2001) membuktikan bahwa auditor wanita lebih akurat dibandingkan dengan auditor pria dalam melakukan penugasan yang kompleks. Wanita lebih berperilaku etis daripada laki-laki. Berdasarkan uraian di atas, maka hipotesis keempat penelitian ini adalah sebagai berikut:

H4: Gender mempengaruhi sensitivitas etis mahasiswa

\section{METODE PENELITIAN}

\section{Deskripsi sampel}

Metode pengumpulan data yang dilakukan dalam penelitian ini adalah dengan menggunakan metode kuesioner. Data dikumpulkan melalui personal. Metode ini menggunakan penyebaran kuesioner yang telah disusun secara terstuktur, sejumlah pertanyaan tertulis disampaikan pada responen untuk ditanggapi sesuai dengan kondisi yang dialami oleh responden yang bersangkutan. Pertanyaan berkaitan dengan data demografi responden serta opini atau tanggapan terhadap sensitivitas etis, modal intelektual, orientasi etika serta gender dari mahasiswa yang telah mengambil matakuliah etika bisnis dan profesi, alasan ini dipilih karena mahasiswa pada level tersebut sudah mendapatkan pengetahuan tentang hal-hal yang pantas dilakukan atau tidak kaitannya dengan bisnis. Mahasiswa diambil dari salah satu Perguruan Tinggi Swasta di Kota Yogyakarta.

\section{Variabel penelitian dan definisi operasional variabel}

Dalam penelitian ini variabel dependennya adalah sensitivitas etis mahasiswa, sedangkan variabel independennya adalah modal intelektual, orientasi etika idealisme, orientasi etika relativisme dan gender. Definisi operasional masing-masing variabel adalah: 
Modal Intellectual diukur dengan menggunakan item pertanyaan tentang kemampuan seseorang untuk menghasikan solusi terbaik berdasarkan pengetahuan. Tujuh item pertanyaan digunakan untuk mengetahui kemampuan mahasiswa dengan tingkat pengetahuannya, informasi yang diperoleh, dan pengalaman yang didapat digunakan untuk memberikan solusi terbaiknya. Pertanyaan menggunakan 1, 2, 4 dan 5 skala likert. Arti dari skor 1 adalah sangat tidak setuju, skor 2 tidak setuju, skor 4 setuju dan skor 5 sangat setuju. Dalam penelitian ini skor 3 atau netral sengaja tidak dicantumkan sebagai pilihan dalam kuesionear, karena menurut pertimbangan peneliti skor netral kurang memberikan manfaat dan cenderung memberikan pilihan kepada responden tidak bertanggung jawab.

Orientasi Etika, Variabel orientasi etika dalam penelitian ini menggunakan instrumen yang disusun oleh (Forsyth 1980) yang juga diadopsi oleh (Ziegenfuss dan Singhapakdi 1994) yaitu Ethics Position Questionaire (EPQ) dengan penyesuaian karena respondennya mahasiswa. EPQ untuk mengukur idealisme dan relativisme, yang merupakan dua faktor dasar dari nilai etika individual. Idealisme adalah suatu sikap yang menganggap bahwa tindakan yang tepat atau benar akan menimbulkan konsekuensi atau hasil yang diinginkan. Seorang individu yang idealis mempunyai prinsip bahwa merugikan individu lain adalah hal yang selalu dapat dihindari dan mereka tidak akan melakukan tindakan yang mengarah pada tindakan yang berkonsekuensi negatif.

Item pertanyaan tentang idealisme menanyakan persepsi mahasiswa tentang keharusan tidak merugikan orang lain, tidak menyakiti orang lain dan harus bermoral. Pertanyaan kuesioner berjumlah 10 dengan menggunakan 1, 2, 4 dan 5 skala likert. Arti dari skor 1 adalah sangat tidak setuju, skor 2 tidak setuju, skor 4 setuju dan skor 5 sangat setuju. Jika individu tersebut sangat setuju dengan pertanyaan tersebut maka diasumsikan bahwa individu tersebut memiliki tingkat idealisme yang tinggi, namun jika individu tersebut sangat tidak setuju maka diasumsikan bahwa individu tersebut memiliki tingkat idealisme yang rendah.

Item pertanyaan tentang relativisme menanyakan persepsi mahasiswa tentang tipe moralitas yang berbeda-beda, etika pribadi, dan kebohongan situasional. Secara umum relativisme berpendapat bahwa manusia, budaya, etika, moral, agama, bukanlah perbedaan hakikat, melainkan perbedaan karena faktor-faktor diluarnya. Pertanyaan kuesioner berjumlah 10 dengan menggunakan 1, 2, 4 dan 5 skala likert. Arti dari skor 1 adalah sangat tidak setuju, skor 2 tidak setuju, skor 4 setuju dan skor 5 sangat setuju. Jika individu tersebut sangat setuju dengan pertanyaan tersebut maka diasumsikan bahwa individu tersebut memiliki tingkat relativisme yang tinggi, namun jika individu tersebut sangat tidak setuju maka diasumsikan bahwa individu tersebut memiliki tingkat relativisme yang rendah.

Gender adanya fenomena professional wanita yang sebanding dengan pria pada saat ini, menjadi salah satu dasar mengapa variabel gender akan mempengaruhi pengambilan keputusan etis. Perbedaan sifat diantara wanita dan pria membuat intensi perilaku dan pola berfikir yang berbeda pula. Indikator penelitian untuk variabel gender terlihat dari demografi responden pada kuesioner, dengan keterangan (1) Wanita, (0) Pria.

Sensitivitas Etis menggunakan skenario yang akan membantu menstandarisasikan stimulus sosial dari responden dan pada saat bersamaan merupakan gambaran yang lebih nyata dalam proses pembuatan keputusan etis. Hal ini sesuai dengan dua tahapan pertama pengambilan keputusan etis menurut (Zeigenfuss dan Martison 2002) yaitu tahapan pemahaman mengenai ada tidaknya muatan etika dan tahapan pengambilan keputusan etis itu sendiri. Pertanyaan 
berkaitan dengan mahasiswa tidak akan melakukan pemalsuan, tindakan kekerasan, pencurian, adu domba, kecurangan, dan pelanggaran perjanjian. Pertanyaan kuesioner berjumlah 5 dengan menggunakan 1, 2, 4 dan 5 skala likert. Arti dari skor 1 adalah sangat tidak setuju, skor 2 tidak setuju, skor 4 setuju dan skor 5 sangat setuju. Jika individu tersebut sangat setuju dengan pertanyaan tersebut maka diasumsikan bahwa individu tersebut memiliki tingkat sentitivitas etis yang tinggi, namun jika individu tersebut sangat tidak setuju maka diasumsikan bahwa individu tersebut memiliki tingkat sentitivitas etis yang rendah.

Analisis data dalam penelitian ini menggunakan analisis regresi berganda. Variabel dependen dalam penelitian ini adalah sensitivitas etis mahasiswa dengan variabel independen adalah modal intelektual, orientasi etika (idealisme dan relativisme) dan gender. Sebelum melakukan uji hipotesis penulis melakukan uji validitas kuesioner untuk mengukur sah atau valid tidaknya suatu kuesioner dan pengujian reliabelnya atau handalnya kuesioner untuk menguji konsistensi jawaban responden.

\section{HASIL DAN PEMBAHASAN}

Kuesioner diberikan secara langsung kepada mahasiswa saat perkuliahan. Responden yang digunakan sebagai sampel adalah mahasiswa yang telah mengambil matakuliah etika bisnis, harapannya mahasiswa dapat membedakan tindakan etis dan tidak etis. Dari sejumlah 100 kuesioner yang disebarkan, 72 kuesioner yang kembali. Kemudian dari 72 kuesioner, 2 tidak terjawab lengkap, sehingga yang diolah dalam penelitian ini hanya 70 kuesioner.

Sebelum pengujian hipotesis, maka peneliti melakukan pengujian validitas untuk mengukur sah atau valid tidaknya suatu kuesioner. Pengujian validitas dalam penelitian ini digunakan loading factor. Kuesioner juga dinilai reliabelnya atau handalnya, jika jawaban seseorang terhadap pertanyaan adalah konsisten atau stabil dari waktu ke waktu maka didapatkan Cronbach Alpha yang besar. Hasil uji validitas dan reliabilitas masing-masing variabel tersaji dalam tabel 1 berikut:

Tabel 1

Uji Validitas dan Reliabilitas Pengukuran

\begin{tabular}{|c|c|c|}
\hline Kode Items & Factor & Alpha \\
\hline \multicolumn{2}{|c|}{ Modal Intelektual } & 0,805 \\
\hline MI1 & 0,57 & \\
\hline MI2 & 0,65 & \\
\hline MI3 & 0,60 & \\
\hline MI4 & 0,79 & \\
\hline MI5 & 0,63 & \\
\hline MI6 & 0,72 & \\
\hline MI7 & 0,77 & \\
\hline \multicolumn{2}{|c|}{ Orientasi Idealisme } & 0,837 \\
\hline OI1 & 0,73 & \\
\hline $\mathrm{OI} 2$ & 0,57 & \\
\hline OI3 & 0,78 & \\
\hline OI4 & 0,81 & \\
\hline OI5 & 0,87 & \\
\hline
\end{tabular}




\begin{tabular}{|l|l|l|}
\hline OI6 & 0,77 & \\
\hline OI7 & 0,79 & \\
\hline OI8 & 0,86 & \\
\hline OI9 & 0,79 & \\
\hline OI10 & 0,81 & \\
\hline Orientasi Relativisme & 0,719 \\
\hline OR1 & 0,70 & \\
\hline OR2 & 0,72 & \\
\hline OR3 & 0,74 & \\
\hline OR4 & 0,73 & \\
\hline OR5 & 0,78 & \\
\hline OR6 & 0,72 & \\
\hline OR7 & 0,74 & \\
\hline OR8 & 0,87 & \\
\hline OR9 & 0,81 & \\
\hline OR10 & 0,83 & \\
\hline Sensitivitas Etis & & 0,883 \\
\hline SE1 & 0,88 & \\
\hline SE2 & 0,92 & \\
\hline SE3 & 0,74 & \\
\hline SE4 & 0,89 & \\
\hline SE5 & 0,84 & \\
\hline
\end{tabular}

Sumber : Ouput SPSS

Dari tabel 1 tersebut menyajikan hasil uji validitas dan reliabilitas. Hasil uji dapat dilihat bahwa penelitian ini mempunyai factor loading lebih besar dari 0,5 , sehingga indikatorindikator tersebut dapat diterima sebagai pengukur variabel laten penelitian. Uji kekonsistenan indikator-indikator dalam satu variabel dilakukan dengan uji reliabilitas Cronbach Alpha, nilai Cronbach Alpha telah melampui rule of thumb alpha sebesar minimal 0,6. Jadi data penelitan ini lolos uji reliabilitas (Ghozali 2011).

Setelah lolos uji validitas dan reliabilitas, maka selanjutnya menguji hipitesis dengan analisis regresi, untuk menguji pengaruh modal intelektual, orientasi etika idealisme, orientasi etika relativisme dan gender terhadap sensitivitas etis mahasiswa. Hasil analisis regresi untuk menguji hipotesis dapat dilihat pada tabel 2 berikut:

Tabel 2 Hasil uji hipotesis

\begin{tabular}{lll}
\hline \hline & Koefisien & $\mathrm{T}$ \\
\hline Constant & 1.876 & 5.910 \\
Modal Intelektual & 0.137 & 2.515 \\
Idealisme & 0.160 & 2.169 \\
Relativisme & 0.416 & 1.830 \\
Gender & 0.172 & 1.000 \\
\hline
\end{tabular}

Dependen Variabel: Sentitivitas Etis

$\mathrm{R}^{2}: 0,254 \quad$ F Statistik: 5.000

Adjusted $\mathrm{R}^{2}$ : 0,052 Signifikansi: 0,008

- signifikan pada $\alpha=5 \%, \mathrm{R}^{2}$ dan Adjusted $\mathrm{R}^{2}$

untuk menguji besarnya korelasi, F Statistik

untuk menguji model 
Hasil uji $\mathrm{F}$ untuk mengetahui apakah variabel independen dapat menjadi prediktor bagi variabel dependen. Nilai $\mathrm{F}$ sebesar 5,000 dengan nilai signifikansi sebesar 0,008 diterima pada taraf signifikansi 5\%. Artinya model regresi mengenai modal intelektual, orientasi etika idealisme, orientasi etika relativisme dan gender terhadap sensitivitas etis signifikan secara statistik. Hal ini menunjukkan bahwa modal intelektual, orientasi etika idealisme, orientasi etika relativisme dan gender dapat memprediksi sensitivitas etis mahasiswa.

Hipotesis satu mengatakan bahwa terdapat pengaruh positif antara modal intelektual dengan sensitivitas etis. Hasil uji regresi didapat nilai koefisien modal intelektual adalah sebesar 0,137 dengan nilai t sebesar 2,515 dan signifikansi $0,013(\mathrm{sig}<0,05)$, berarti variabel modal intelektual berpengaruh secara positif terhadap sensitivitas etis mahasiswa.

Hipotesis dua mengatakan bahwa terdapat pengaruh positif antara orientasi etika idealisme dengan sensitivitas etis. Hasil uji regresi didapat nilai koefisien orientasi etika idealisme sebesar 0,160 dengan nilai $\mathrm{t}$ sebesar 2,169 dan signifikansi $0,032 \quad($ sig $<0,05$ ), berarti variabel orientasi etika idealisme berpengaruh secara positif terhadap sensitivitas etis mahasiswa.

Hipotesis tiga mengatakan bahwa terdapat pengaruh antara orientasi etika relativisme dengan sensitivitas etis. Hasil uji regresi didapat nilai koefisien orientasi etika relativisme sebesar 0,416 dengan nilai $\mathrm{t}$ sebesar 1,830 dan signifikansi 0,072 (sig $>0,05$ ), berarti variabel orientasi etika relativisme tidak signifikan berpengaruh sensitivitas etis mahasiswa. Hasil uji hipotesis empat nilai koefisiennya sebesar 0,172 dengan nilai $t$ sebesar 1,000 dan signifikansi 0,321, sehingga variabel gender juga tidak signifikan berpengaruh sensitivitas etis mahasiswa.

Dari hasil pengujian determinasi menghasilkan nilai $\mathrm{R}^{2}$ dan Adjusted $\mathrm{R}^{2}$ sebesar 0,254 dan 0,052 sehingga dapat dikatakan bahwa korelasi variabel modal intelektual, orientasi etika idealisme, orientasi etika relativisme dan gender terhadap sensitivitas etis sebesar $25,4 \%$ $(5,2 \%)$, sehingga masih banyak variabel yang belum terobservasi dalam penelitian ini.

Hasil pengujian ini sesuai dengan Theory Planned of Behavior yang mengasumsikan bahwa manusia biasanya akan berperilaku pantas dengan dasar tiga fungsi dasar determinan, yaitu : (1) attitude toward the behavior, (2) subjective norm, (3) perceived behavior control. Fungsi dasar determinan attitude toward behavior dan subjective norm mampu menjelaskan sikap dari diri sesorang, sesuai dengan lingkungan dan norma-norma yang diyakini orang-orang di sekitarnya. Orang lain akan menilai seseorang yang berkeahlian tinggi pasti akan berperilaku baik, oleh karena itu setiap individu dengan keahlian tertentu biasanya akan bersikap sesuai dengan bagaimana persepsi orang lain terhadap dirinya. Hasil pengujian ini menunjukkan bahwa semakin banyak pengetahuan yang dimiliki oleh mahasiswa maka mahasiswa tersebut dalam bertindak berdasarkan pengetahuannnya tentang etika. Dengan adanya pengetahuan yang dimiliki maka akan berpengaruh terhadap penalaran yang diberikan individu dalam tiap tahapan perkembangan moral sehingga terdapat perubahan perkembangan dan perilaku pada tiap tahap perkembangan moral individu.

Mahasiswa dengan idealisme tinggi akan menjunjung tinggi nilai-nilai etika. Idealisme yang tinggi akan membawa mahasiswa kepada orientasi etika dan selalu memegang teguh sesuai dengan aturan yang berlaku. Hal ini mengindikasikan pentingnya pembelajaran etika pada 
setiap level perkuliahan, sehingga memberikan pemahaman yang baik mengenai etika dan proses pembelajaran yang efektif, akhirnya saat dihadapkan pada kasus sensitivitas etis mahasiswa dapat memberikan penilaian dengan tegas. Hal ini sesuai dengan penelitian (Hunt dkk 1989) yang menyatakan bahwa nilai etika organisasi merupakan komponen sangat penting dalam kultur organisasi dan secara interaktif merupakan pembentuk orientasi etika individu dalam organisasi. Temuan ini menunjukkan bahwa orientasi etika mahasiswa berpengaruh secara positif terhadap keputusan yang diambil dalam situasi dilema etika.

Hasil pengujian orientasi etika relativisme tidak signifikan, hal ini menunjukkan bahwa individu yang memiliki sifat relativisme akan lebih fleksibel dalam menanggapi suatu kasus, sehingga saat memutuskan kasus yang berkaitan dengan sensitivitas etis akan menyesuaikan keadaan dan terpaksa harus melakukan perilaku yang tidak sesuai dengan sikapnya. Sesuai teori disonansi disaat individu merasakan akan menimbulkan ketidaknyamanan psikologis, hal ini akan memotivasi seseorang untuk mengurangi disonansi tersebut dan mencapai konsonansi. Artinya pada saat timbul suatu inkonsistensi dan perasaan tidak suka yang mendorong orang untuk melakukan suatu tindakan untuk keluar dari ketidaknyamanan tersebut dengan dampak-dampak yang tidak dapat diukur.

Disonansi terjadi apabila terdapat hubungan yang bertolak belakang akibat penyangkalan dari satu elemen kognitif terhadap elemen lain, antara elemen-elemen kognitif dalam diri inidividu. Disonansi kognitif mengacu ada inkonsistensi dari dua atau lebih sikap-sikap individu, atau inkonsistensi antara perilaku dan sikap. Unsur kognitif yang terjadi berdasar pengetahuan, opini, atau apa saja yang dipercayai orang mengenai lingkungan, diri sendiri atau perilakunya mampu membantu untuk meprediksi kecenderungan individu dalam mengubah sikap dan perilaku dalam rangka untuk mengurangi disonansi yang terjadi.

Hasil pengujian menemukan gender tidak signifikan mempengaruhi sensitivitas etis mahasiswa. Mahasiswa yang bergender perempuan belum tentu akan menilai sensitivitas etis dengan lebih baik dari pada laki-laki. Hal ini menunjukkan bahwa individu yang bergender perempuan dan laki-laki tidak terdapat perbedaan intensitas etis maupun evaluasi etis. Hasil ini konsisten dengan teori fungsional struktural. Teori ini dipengaruhi oleh adanya asumsi kesamaan antara kehidupan organisme biologis dan struktur sosial tentang adanya keteraturan dan keseimbangan dalam masyarakat.

Asumsi dasar teori fungsional struktural, yaitu bahwa masyarakat terintegrasi atas dasar kesepakatan dari para anggotanya akan nilai-nilai kemasyarakatan tertentu yang mempunyai kemampuan mengatasi perbedaan-perbedaan sehingga masyarakat tersebut dipandang sebagai suatu sistem yang secara fungsional terintegrasi dalam suatu keseimbangan. Pekerjaan membentuk perilaku melalui struktur reward, laki-laki dan perempuan akan memberi respon yang sama pada lingkungan jabatan yang sama. Jadi pendekatan struktural memprediksikan bahwa laki-laki dan perempuan yang mendapat pelatihan dan jabatan yang sama akan menunjukkan prioritas etis yang sama pula.

\section{SIMPULAN}

Tujuan dari penelitian ini adalah untuk menguji pengaruh modal intelektual, orientasi idealisme, orientasi relativisme dan gender terhadap sensitivitas etis mahasiswa. Berdasarkan hasil uji statistika maka dapat disimpulkan bahwa modal intelektual dan orientasi idealisme mempengaruhi sensitivitas etis mahasiwa. Sedangkan untuk variabel orientasi relativisme dan gender tidak mempengaruhi sensitivitas etis mahasiwa. Hasil pengujian ini menunjukkan 
bahwa semakin banyak pengetahuan yang dimiliki oleh mahasiswa maka akan berpengaruh terhadap penalaran yang diberikan individu dalam tiap tahapan perkembangan moral sehingga terdapat perubahan perkembangan dan perilaku pada tiap tahap perkembangan moral individu. Berdasarkan hasil penelitian ini maka berimplikasi pada materi ajar yang harus didesain dengan memasukkan materi etika pada tiap-tiap level pembelajaran.

Mahasiswa dengan idealisme tinggi akan menjunjung tinggi nilai-nilai etika dan selalu memegang teguh sesuai dengan aturan yang berlaku. Hal ini mengindikasikan pentingnya pembelajaran etika pada setiap level perkuliahan, sehingga memberikan pemahaman yang baik mengenai etika dan proses pembelajaran yang efektif, akhirnya saat dihadapkan pada kasus sensitivitas etis mahasiswa dapat memberikan penilaian dengan tegas. Temuan ini menunjukkan bahwa orientasi etika idealisme mahasiswa berpengaruh secara positif terhadap keputusan yang diambil dalam situasi dilema etika.

Individu yang memiliki sifat relativisme akan lebih fleksibel dalam menanggapi suatu kasus, sehingga saat memutuskan kasus yang berkaitan dengan sensitivitas etis akan menyesuaikan keadaan dan terpaksa harus melakukan perilaku yang tidak sesuai dengan sikapnya. Saat individu pada posisi ketidaknyamanan psikologis, maka akan memotivasi seseorang untuk melakukan suatu tindakan untuk keluar dari ketidaknyamanan tersebut dengan dampakdampak yang tidak dapat diukur. Berdasar pengetahuan, opini, atau apa saja yang dipercayai orang mengenai lingkungan, diri sendiri atau perilakunya maka individu tersebut akan mengubah sikap dan perilakunya.

Mahasiswa yang bergender perempuan belum tentu akan menilai sensitivitas etis dengan lebih baik dari pada laki-laki. Hal ini menunjukkan bahwa individu yang bergender perempuan dan laki-laki tidak terdapat perbedaan intensitas etis maupun evaluasi etis. Hasil ini konsisten dengan teori fungsional structural, laki-laki dan perempuan akan memberi respon yang sama pada lingkungan jabatan yang sama, laki-laki dan perempuan yang mendapat pelatihan dan jabatan yang sama akan menunjukkan prioritas etis yang sama pula.

\section{Keterbatasan}

Dari sisi metoda, penelitian ini belum menunjukkan hasil yang memuaskan seperti jumlah responden yang terbatas sehingga dalam penelitian belum dapat digunakan untuk menarik kesimpulan secara umum. Untuk memperjelas hasil penelitian ini, maka perlu dilakukan penelitian lebih lanjut yang mengeksplorasi hubungan faktor-faktor lain yang dapat mempengaruhi pengambilan keputusan etis mahasiswa dalam situasi dilema etika atau dapat juga dibandingkan dengan pelaku bisnis yang telah berpengalaman.

\section{Implikasi}

Terlepas dari berbagai keterbatasan yang ada dalam penelitian ini, hasil penelitian ini diharapkan dapat memberikan masukan bagi berbagai pihak yang terkait dengan materi ajar terutama berkaitan sensitivitas etis. Kompleknya proses pengambilan keputusan dalam situasi dilema etis merupakan hal yang harus bisa ditangkap oleh mahasiswa agar proses pembelajaran mampu menciptakan calon pebisnis yang kualified dan etis, memiliki kecerdasan intelektual setara dengan kepekaan nurani, sehingga mampu menciptakan sebuah investasi dan esensi yang sesungguhnya dari konsep human capital. 


\section{DAFTAR REFERENSI}

Ajzen, I. 1991. The Theory of Planned Behavior. Organizational Behavior and Human Decision Processes. 179-211

Barnett, T. K. Bass dan G. Brown. 1994. Ethical Ideology and Ethical Judgment Regarding Ethical Issues in Business. Journal of Business Ethics. vol.13.

Becker. Gary S. 1964. Human Capital: A Theoretical and Empirical Analysis, with Special Reference to Education. Chicago. University of Chicago Press.

Bontis, Nick. 2005. National Intellectual Capital Index: The Benchmarking of Arab Countries. Boudreau

Chung, J and Monroe, G. 2001. A research note on the effects of gender and task complexity on an audit judgment, Behavioral Research in Accounting, Vol. 13 : 111-126

Clark, C.K. 2003. Reviewing the Value Ethic Education. Pennsylvania CPA Journal. Vol. 74. No.2.

Cohen, J.R., L.W. Pant dan D.J. Sharp. 1996. Measuring the Ethical Awareness and Ethical Orientation of Canadian Auditors. Behavioral Research in Accounting,Vol. 8. Supplement.

Cytron, Scot H. 2005. Evolving Curricula: Ethics Proposal Stirs Debate. Catalyst, September - Oktober.

Drucker, Peter F. 1997. Manajemen di Tengah Perubahan Besar. Jakarta: Elex Media Komputindo.

Drucker, Peter F. 2001. The Essential Drucker. New York: Harper Collins. Fitz-enz, Jac. 2000. The ROI of Human Capital: Measuring the Economic Value of Employee Performance. New York: AMACOM.

Ghozali, Imam. 2011. Aplikasi Analisis Multivariate dengan Program SPSS 19. Edisi 5. Semarang: Badan Penerbit Universitas Diponegoro

Hunt, S.D.; V.R. Wood dan L.B. Chonko. 1989, Corporate Ethical Values and Organizational Commitment in Marketing, Journal of Marketing, Vol. 53 (July).

Huss, H. Fenwick dan Denies M. Patterson. 1993. Ethics in Accounting: Values Education without Indoctrination. Journal of Business Ethics. vol 12 (3):235 - 243

Jones, T.M. 1991. Ethical Decision Making by Individuals in Organizations: An IssueContingent Model. Academy of Management Review, Vol. 16 No. 2, hal. 366-395.

Loe, T.W., L. Ferrel dan P. Mansfield. 2000. A Review of Empirical Studies Assesing Ethical Decision Making in Business. Journal of Business Ethics. Vol. 25, hal. 185-204. 
Louwers, T.J.; L.A. Ponemon dan R.R. Radtke. 1997. Examining Accountants' Ethical Behavior: A Review and Implications for Future Research dalam Behavioral Accounting Research: Foundation and Frontiers, Editor Vicky Arnold dan Steve G. Sutton

Nahapiet, Janine and Sumantra Ghoshal. 1998. Social Capital, Intellectual Capital, and the Organizational Advantage. Academy of Management Review Vol 23 No. 2, 242-266.

Paolillo, J.G.P dan S.J. Vitell. 2002. An Empirical Investigation of the Influence of Selected Personal, Organizational and Moral Intensity Factors on Ethical Decision Making", Journal of Business Ethics 35. hal. 65-74.

Radtke, R.R. 2000. The Effect of Gender and Setting on Accountants' Ethically Sensitive Decisions. Journal of Business Ethics. Vol 24(4). 299-312

Russel, K.A dan C.S. Smith. 2003. Accounting Education's Role in Corporate Malfeasance: Its's Time for a New Curriculum, Strategic Finance, Vol. 85, No.6

Sankaran. S. dan Bui, T. 2003. Relationship between student's characteristics and ethics:Implications for educators. Journal of Instructional Psychology. 30 (3). pp. 240253

Severin, Werner J. 2005. Teori Komunikasi; Sejarah, Metode Dan Terapan Dalam Media Massa. terjemahan. Sugeng Hariyanto. Jakarta: Kencana

Stewart, T. 1997. Intellectual capital: the new wealth of organizations. New York, NY: Doubleday.

Trevino, L.K. 1986. Ethical Decision Making in Organizations: A Person-Situation Interactionist Model. Academy of Management Review, Vol. 11. No. 3.

Ziegenfuss, D.E. dan O.B. Martinson. 2002. The IMA Code of Ethics and IMA Members' Ethical Perception and Judgment. Managerial Auditing Journal, Vol. 17 No. 4.

Ziegenfuss, D.E. dan A. Singhapakdi. 1994. Professional Values and Ethical Perceptions of Internal Auditors. Managerial Auditing Journal, Vol. 9 No. 1. 